\title{
BUDAYA SIRI' NA PACCE DAN SIPAKATAU DALAM INTERAKSI SOSIAL MASYARAKAT SULAWESI SELATAN
}

\author{
Auliah Safitri $\left({ }^{1 *}\right)$, Suhamo $\left({ }^{2}\right)$ \\ ${ }^{12}$ Department of Civic Education, Graduate School of Universitas Negeri Yogyakarta, Indonesia.
}

\begin{tabular}{ll} 
ARTICLE INFORMATION \\
\hline Submitted & $: 09^{\text {th }}$ September, 2019 \\
Review & $: 02^{\text {nd }}$ March, 2020 \\
Accepted & $: 13^{\text {th }}$ May, 2020 \\
Published & $: 1^{\text {st }}$ June, 2020 \\
Available Online & $:$ June, 2020 \\
KEYWORDS & \\
\hline
\end{tabular}

Siri' Na Pacce; Sikapatau; Social Interaction

\section{CORRESPONDENCE}

*E-mail: auliahsyafitri@yahoo.com

A B S T R A C T
The plurality of Indonesian, beside of becoming a property, also
becoming a boomerang for the unity of a nation. The conflict that
arises will not resolve if they are left casually. The disputes can be
overcome and avoided if the society can build positive social
interaction among fellow. Therefore, in facing conflicts, it is necessary
to realize that an ethnic group is not a social group that must be
considered by, however, a local knowledge that is store in a culture of
ethnic groups. This research aims to determine the social interaction
of South Sulawesi's communities, namely the ethnic of Bugis,
Makassar, Mandar, and Toraja. Those four ethnics have had cultural
characteristics that have been being a customs and philosophies of
their lives because they have normative elements values that can bind
their members. This research is compiled through a literature study in
which the data obtained from various books and journals. The result
reveals that the ethnics of South Sulawesi have been building social
interaction based on the culture of Siri' Na Pacce and Sipakatau,
which are the main foundation in building positive communication
among fellow. Those cultures must be well implemented and
maintained in building social interaction.

\section{A. PENDAHULUAN}

$\mathrm{M}$ anusia di dalam menjalankan kehidupannya sebagai makhluk sosial dan bagian dari masyarakat tidak dapat terlepas dari anggota masyarakat lainnya. Manusia akan selalu membutuhkan manusia lainnya untuk dapat berinteraksi maupun bertukar pikiran. Pola hubungan tersebut akan membangun interaksi sosial dalam masyarakat. Interaksi sosial adalah hubungan-hubungan sosial yang bersifat dinamis yang berkaitan dengan orang perorangan, kelompok perkelompok, maupun perorangan terhadap kelompok atau sebaliknya (Setiadi \& Kolip, 2011). Dalam interaksi sosial, terjadi hubungan timbal balik antara individu dengan individu, individu dengan kemlompok, dan kelompok dengan kelompok (Soekanto, 2010).

Pada dasarnya dalam hubungan interaksi sosial, dapat terjadi interaksi positif ataupun negatif. Interaksi positif terjadi apabila terdapat hubungan timbal balik yang saling menguntungkan. Sementara interaksi negatif terjadi jika hubungan timbal balik merugikan satu pihak atau keduanya (bermusuhan). Interaksi sosial inilah yang menjadi pondasi dari hubungan yang berupa tindakan berdasarkan norma dan nilai sosial yang berlaku. Interaksi sosial dapat berlangsung dengan baik jika aturan-aturan dan nilai-nilai yang ada dapat dilakukan dengan baik. Jika tidak ada kesadaran atas pribadi masingmasing maka proses interaksi sosial itu sendiri 
tidak akan dapat berjalan sesuai dengan yang diharapkan. Pada proses interaksi sosial akan ada hubungan saling mempengaruhi antar satu dengan yang lain atau bisa disebut dengan give and take baik secara lisan maupun perbuatan yang dapat menimbulkan perubahan di dalam perasaan dan juga kesan yang ada dalam pikiran dan selanjutnya bisa menentukan tindakan yang akan dilakukan.

Dalam berbagai macam kelompok sosial di mana manusia menjadi anggota-anggotanya seperti kekeluargaan, keorganisasian, dan berbagai macam kelompok lainnya, setiap anggota akan melakukan interaksi antar satu dengan yang lainnya secara langsung ataupun tidak langsung.

Interaksi-interaksi sosial yang terjadi di dalam kehidupan sehari-hari masyarakat muncul sebagai akibat dari kemajemukan dan pluralisme budaya Indonesia (Purbasari \& Suharno, 2019). Interaksi manusia dengan sesamanya dalam kehidupan bertujuan untuk menghasilkan pergaulan hidup dalam kelompok sosial. Pergaulan hidup akan terjadi apabila manusia dalam hal ini orang perorangan atau kelompokkelompok manusia yang bekerja sama saling berbicara untuk mencapai tujuan bersama.

Indonesia dengan kemajemukannya mampu menjadi satu kesatuan yang dibangun dari beberapa perbedaan baik dari segi budaya, suku, ras, dan agama. Indonesia dengan berbagai keberagaman tersebut juga mampu menjadi satu yang berlandaskan pada Pancasila dan Bhineka Tunggal Ika. Namun dalam kenyataannya konflikkonflik dalam keberagaman yang timbul sebagai akibat dari interaksi sosial tidak dapat dihindarkan. Konflik pada dasarnya merupakan sebuah hal yang selalu ada dan sulit untuk dipisahkan dalam kehidupan sosial. Konflik sosial merupakan gambaran tentang perselisihan, percekcokan, ketegangan atau pertentangan sebagai akibat dari perbedaan-perbedaan yang muncul dalam kehidupan masyarakat, baik perbedaan yang bersifat individual maupun perbedaan kelompok (Irwandi \& Chotim, 2017).

Samovar et al. (2009) mendefinisikan beberapa definisi konflik. Pertama, konflik adalah pertentangan antara banyak kepentingan, nilai, atau arah serta merupakan bagian yang menyatu sejak kehidupan ada. Karenanya konflik merupakan sesuatu yang tidak terelakkan yang dapat bersifat positif atau negatif. Kedua, konflik adalah suatu hubungan yang melibatkan dua orang atau lebih yang memiliki atau merasa memiliki kepentingan dan tujuan yang bertentangan. Ketiga, konflik adalah proses pertentangan yang diekspresikan di antara dua pihak atau lebih yang saling tergantung mengenai suatu objek konflik, menggunakan pola perilaku dan interaksi yang menghasilkan keluaran konflik.

Terjadinya konflik biasanya dipicu oleh beberapa faktor. Menurut Muslim (2013), beberapa permasalahan yang dapat memicu konflik dalam interaksi sosial antara lain etnosentrisme, misunderstanding of culture values, stereotip, dan prasangka. Permasalahan pertama adalah etnosentrisme. Etnosentrisme merupakan suatu sikap yang membuat kebudayaan diri menjadi patokan dalam mengukur baik buruk, tinggi rendah, dan benar salah kebudayaan lain. Lalu permasalahan kedua adalah tentang kesalahpahaman antar budaya. Sebagai contoh kecil, mabbuse dalam bahasa Sidrap sering digunakan kepada orang yang dipersilahkan. Namun bagi orang Bone, istilah tersebut memiliki konotasi yang merendahkan harga diri bahkan dianggap sebagai sebuah pelecehan. Perbedaanperbedaan semacam ini di sisi lain sebagai khasanah dan kebudayaan yang dimiliki Indonesia, namun pada sisi lain merupakan bumerang akan lahirnya disintegrasi sosial. Permasalahan ketiga adalah stereotip, yaitu keyakinan yang terlalu menggeneralisir, disederhanakan, atau dilebih-lebihkan terhadap kelompok etnis tertentu. Dan persoalan yang terakhir adalah prasangka, yaitu sikap yang tidak beralasan terhadap outgroup yang didasarkan pada komparasi dengan ingroup seseorang.

Indonesia dengan kemajemukan yang dimiliki juga acap kali dihadapkan dengan beberapa konflik serius yang mengancam persatuan dan kesatuan Bangsa. Pada tahun 2017 lalu terjadinya kasus penistaan agama yang dilakukan oleh seorang Gubernur. Pada tahun 2019 terjadi konflik yang disebabkan oleh diskriminasi suku sehingga suku tersebut mengambil sikap yang sangat ekstrim dan semakin mantap untuk memisahkan diri dari Indonesia. Konflik-konflik semacam ini bisa saja diprakarsai oleh permasalahan seperti etnosentrisme, kesalahpahaman, stereotip, maupun prasangka. Dari konflik-konflik tersebut dapat kita pahami bahwa agama dan suku adalah dua hal yang sifatnya sangat sensitif. 
Oleh sebab itu, hendaknya ucapan dan perbuatan tentang kedua hal tersebut maupun indikator kemajemukan lainnya tetap harus dijaga demi persatuan dan kesatuan Indonesia.

Soetopo (1999) mengklasifikasikan jenis konflik yang dipandang dari segi materinya. Pertama, konflik tujuan, terjadi jika ada dua tujuan yang kompetitif bahkan yang kontradiktif. Kedua, konflik peranan, terjadi jika manusia memiliki lebih dari satu peranan dan tiap peranan tidak selalu memiliki kepentingan yang sama. Ketiga, konflik nilai muncul karena perbedaan nilai yang dimiliki setiap individu dalam organisasi sehingga konflik dapat terjadi antar individu, individu dengan kelompok, bahkan kelompok dengan organisasi. Kelima, konflik kebijakan, yaitu suatu konflik yang terjadi karena ada ketidaksetujuan individu atau kelompok terhadap perbedaan kebijakan yang dikemukakan oleh satu pihak dan kebijakan lainnya.

Anggapan yang menyatakan bahwa konflik dapat teratasi dengan sendirinya apabila dibiarkan merupakan anggapan yang salah karena kenyataannya konflik akan terus berkembang dan akan semakin sulit dikelola apabila tidak segera diselesaikan (Anggraini, 2019). Dalam menghadapi dan menghindari konflik-konflik tersebut, diperlukan kebudayaan yang di dalamnya mengandung nilai-nilai normatif karena kebudayaan memiliki kekuatan memaksa setiap pendukungnya untuk mematuhi segala aturan yang melekat. Seperti yang dijelaskan Dharmawan (2019) bahwa budaya terdiri dari seperangkat nilai-nilai yang dipelajari, keyakinan, standar-standar, pengetahuan, moral, hukum, dan perilaku yang disampaikan oleh individu atau masyarakat yang menentukan bagaimana seseorang bertindak dan memandang dirinya dan yang lain. Senada dengan pendapat Soekanto (2010) yang menyatakan bahwa kebudayaan mencakup semua yang telah didapat atau dipelajari oleh manusia sebagai anggota masyarakat yang meliputi segala sesuatu yang dipelajari dari pola prilaku normatif. Dalam konteks budaya, manusia disebut sebagai animal simboly yang merupakan makhluk yang penuh simbol dan makhluk budaya yang hidupnya terbentuk oleh produk budaya (Larasati, 2018). Lebih lanjut ia menjelaskan bahwa budaya tidak diwariskan melalui kode genetik, melainkan melalui proses enkulturasi yaitu proses interaksi manusia di mana seorang individu belajar dan menerima budayanya.

Setiap bangsa, etnik dan sub etnik memiliki kebudayaan yang dipandang sebagai manifestasi kehidupan setiap orang atau kelompok orang (Ode \& Rachmawati, 2017). Kebudayaan yang tersimpan dalam suku bangsa atau etnik mengandung unsur-unsur dan aspek-aspek sosial yang menjadi pembeda dengan suku bangsa lainnya, misalnya sistem ekonomi, pengetahuan dan teknologi, kepercayaan, politik organisasi sosial, bahasa, dan kesenian. Unsurunsur kebudayaan tersebut yang dapat digunakan sebagai media resolusi konflik antara lain sistem bahasa, sistem peralatan hidup dan teknologi, sistem ekonomi dan mata pencarian hidup, sistem kemasyarakatan dan organisasi sosial, kesenian, dan sistem kepercayaan atau agama.

Unsur pertama adalah sistem bahasa. Bahasa merupakan alat komunikasi yang efektif dalam proses pergaulan manusia. Begitupun dengan bahasa lokal yang diharapkan mampu mengkomunikasikan gagasan-gagasan perdamaian untuk mengakhiri konflik baik dalam fase pra-konflik maupun pasca-konflik. Unsur kedua yaitu sistem peralatan hidup dan teknologi. Unsur ini dapat digunakan sebagai media untuk mengembangkan kehidupan di level lokal dengan baik dan terus mengalami perkembangan walau masih bersifat sederhana. Dengan adanya kehidupan yang stabil, harmonis, dan kondusif maka potensi-potensi yang menggiring ke arah terjadinya konflik dapat diredam.

Unsur ketiga yaitu sistem ekonomi dan mata percaharian hidup. Unsur ini memiliki potensi besar untuk menciptakan peluang terjadinya konflik sosial. Sistem ekonomi masyarakat lokal dan juga mata pencaharian hidup masyarakat lokal syarat akan nilai-nilai yang mampu menciptakan harmoni dalam masyarakat. Begitu juga dengan sistem mata pencarian hidup masyarakat lokal yang tetap memegang teguh prinsip toleransi, kebersamaan, dan juga kesetiakawanan sosial. Unsur ketiga yaitu sistem kemasyarakatan dan organisasi sosial. Unsur ini memegang peranan yang penting sebagai media resolusi konflik di masyarakat. Keberadaan pihak-pihak dalam organisasi-organisasi sosial di tingkat lokal diharapkan menjadi penguat persatuan dan konsolidasi masyarakat di level akar rumput sekaligus juga memainkan peran 
sebagai mediator dalam proses resolusi maupun rekonsiliasi konflik.

Unsur kelima yaitu kesenian. Keberadaan kesenian dapat berfungsi sebagai media untuk mempersatukan masyarakat. Kesenian memiliki nilai-nilai universal yang mampu mempersatukan masyarakat baik di level lokal maupun global. Media-media kesenian berfungsi sebagai media propaganda untuk mengakhiri konflik. Unsur yang keenam sekaligus terakhir yaitu sistem kepercayaan atau agama. Sistem kepercayaan atau agama yang dianut masyarakat dipercaya terus mempromosikan pesan-pesan perdamaian kepada pemeluknya. Asumsi bahwa setiap agama tidak mengajarkan tentang kekerasan diyakini mampu secara efektif membentengi para pemeluknya dari upaya profokasi yang berujung pada konflik.

Berdasarkan penelitian terdahulu yang dilakukan oleh Ode dan Rachmawati (2017) diperoleh kesimpulan bahwa kebudayaan lokal mampu membantu upaya resolusi atas konflikkonflik sosial yang terus terjadi di masyarakat. Nilai-nilai budaya lokal masih dipandang efektif sebagai alat untuk menjaga agar tatanan masyarakat tetap stabil dan harmonis sehingga potensi-potensi konflik dapat diredam sedini mungkin dan dapat diatasi ketika konflik telah terlanjur terjadi. Penelitian terdahulu selanjutnya yang berkaitan dengan kebudayaan lokal dalam memperkuat solidaritas ialah penelitian yang dilakukan oleh Hasbullah (2012) yang menyoroti tentang budaya Rewang di Desa Bukit Batu Kabupaten Bengkalis. Hasbullah menyimpulkan bahwa dalam tradisi rewang terdapat nilai-nilai sosial yang perlu dipertahankan seperti semangat goyong-royong, solidaritas sosial, egaliter dan semangat berkorban untuk orang lain, baik berkorban waktu, materi, maupun tenaga. Dengan demikian, tradisi ini dapat mewujudkan rasa kebersamaan dan solidaritas sosial sehingga dapat mengurangi berbagai ketegangan di tengah masyarakat dan sifat individualistis. Oleh sebab itu, tradisi rewang dapat mempererat rasa kebersamaan dan juga dapat mewujudkan kerukunan di tengah masyarakat baik dilihat dari aspek sosial maupun agama.

Oleh sebab itu, dengan berbagai konflik atas dasar kemajemukan, yang perlu disadari adalah bahwa bukan suku bangsa sebagai kelompok sosial yang harus diperhatikan, tetapi pengetahuan lokal (local knowledge) yang tersimpan di dalam kebudayaan suku bangsa seperti unsur-unsur kebudayaan yang telah dibahas sebelumnya. Pengetahuan lokal yang penting untuk dipahami salah satunya adalah dari Provinsi Sulawesi Selatan yaitu suku Bugis, Makassar, Mandar, dan Toraja yaitu budaya siri' na pacce dan sipakatau. Kebudayaan-kebudayaan ini menjadi penting untuk dilestarikan dan dikembangkan karena di dalamnya terkandung nilai-nilai yang bersifat normatif yang bisa menjadi alat pemersatu sekaligus menghindari konflik yang terjadi karena bumerang dari kemajemukan bangsa Indonesia. Sebagaimana yang termaktub dalam Permendagri Nomor 39 Tahun 2007 Tentang Pedoman Fasilitas Organisasi Kemasyarakatan Bidang Kebudayaan, Keraton, dan Lembaga Adat dalam Pelestarian dan Pengembangan Budaya Daerah bahwa, pertama, Pelestarian Budaya Daerah adalah upaya untuk memelihara sistem nilai sosial budaya yang dianut oleh komunitas/ kelompok masyarakat tertentu di daerah, yang diyakini akan dapat di dalamnya terdapat nilainilai, sikap serta tata cara masyarakat yang diyakini dapat memenuhi kehidupan warga masyarakat. Kedua, Pengembangan Budaya Daerah adalah upaya untuk meningkatkan kualitas sistem nilai sosial budaya yang dianut oleh komunitas/ kelompok masyarakat tertentu di daerah yang diyakini akan dapat memenuhi harapan-harapan warga masyarakat dan di dalamnya terdapat nilai-nilai, sikap serta tata cara masyarakat yang diyakini dapat memenuhi kehidupan masyarakat.

Berdasarkan latar belakang dan penelitian sebelumnya, tulisan ini bertujuan untuk mengkaji bagaimana budaya siri' na pacce dan sipakatau yang menjadi dasar interaksi sosial masyarakat Sulawesi Selatan sebagai upaya untuk menjaga hubungan individu dengan individu, individu dengan kelompok, dan kelompok dengan kelompok.

\section{B. METODE PENELITIAN}

M etode yang digunakan dalam penelitian ini adalah studi kepustakaan (library research) yaitu sebuah metode pengumpulan data melalui telaah terhadap sumber-sumber kepustakaan (Mahmud, 2011). Kajian pustaka atau studi pustaka merupakan kegiatan yang diwajibkan dalam penelitian 
karena memiliki tujuan utama untuk mengembangkan aspek teoretis maupun aspek praktis (Sukardi, 2013). Metode penelitian ini dilakukan dengan cara mengolah data yang berasal dari buku, jurnal, skripsi, maupun tesis yang berhubungan dengan budaya siri' na pacce dan sipakatau dalam interaksi sosial masyarakat Sulawesi Selatan. Setelah diolah, data kemudian dianalisis, dirangkum, dan digeneralisasikan dengan menggunakan kajian teori yang relevan sehingga menjadi satu kesatuan artikel yang utuh.

\section{HASIL DAN PEMBAHASAN}

$\mathrm{B}$ eberapa konflik yang timbul sebagai akibat dari kemajemukan Indonesia perlu dipandang sebagai hal serius yang harus diselesaikan secara komprehensif. Semaksimal mungkin pula harus diupayakan konflik-konflik tersebut tidak terjadi lagi di masa mendatang. Meskipun kemajemukan Indonesia justru bisa menjadi bumerang, tetapi budaya-budaya yang ada di dalamnya harus bisa diimplementasikan dengan baik.

Dalam konteks keberagaman suku dan budaya, setiap wilayah provinsi di Indonesia tentunya memiliki ciri khas suku dan kebudayaan masing-masing. Salah satunya adalah Provinsi Sulawesi Selatan dengan Kota Makassar sebagai ibu kota. Secara umum, Provinsi Sulawesi Selatan memiliki empat suku bangsa, yaitu Suku Bugis, Makassar, Mandar, dan Toraja. Meskipun keempat suku tersebut memiliki ciri khas masingmasing, namun memiliki beberapa adat istiadat dan falsafah yang sama yang dijadikan sebagai landasan dalam membangun interaksi sosial. Seperti yang di bahas pada bab sebelumnya, kebudayaan dan pengetahuan budaya yang penting dikaji sebagai bentuk interaksi sosial masyarakat Sulawesi Selatan sekaligus bisa dijadikan sebagai resolusi konflik yang tengah terjadi di Indonesia yaitu budaya siri' na pacce dan sipakatau. Di dalam budaya-budaya ini terkandung nilai-nilai yang bersifat normatif yang bisa menjadi landasan utama untuk membangun interaksi sosial yang positif.

\section{Budaya Siri' Na Pacce sebagai Harga Diri dan Solidaritas Kemanusiaan}

Solidaritas adalah kesamaan rasa, senasib, dan sepenanggungan. Tidak ada masyarakat yang hidup tanpa adanya solidaritas di dalamnya. Solidaritas kemanusiaan merupakan komponen penting dalam kehidupan kelompok agar selalu menjaga keberadaan kelompok dan bagaimana solidaritas sosial yang terbangun antar anggota kelompok bisa menjadi keseluruhan. Di dalam kehidupan kelompok harus muncul kesadaran kolektif yang dapat menumbuhkan perasaanperasaan atau sentimen atas dasar kesamaan sehingga tercipta rasa solidaritas sosial untuk mencapai tujuan bersama. Faktor-faktor yang mendukung adanya solidaritas dari dalam diri individu hendaknya ditumbuhkembangkan menjadi kebiasaan positif. Solidaritas tidak hanya sebatas teori saja yang memiliki tujuan dan peranan penting dalam kehidupan, melainkan suatu praktik yang bersifat rendah hati, tulus dari dalam diri dan dilakukan secara terus menerus (Kinasih \& Dahliyana, 2018). Budaya siri' na pacce dalam kehidupan suku di Makassar menjadi salah satu faktor pendukung untuk mempertahankan nilai solidaritas kemanusiaan.

Kata siri' dalam bahasa Makassar berarti malu atau rasa malu, maksudnya "siri' lanri anggaukanna anu kodi", artinya malu apabila melakukan perbuatan tercela. Pengertian siri' menurut istilah dapat dilihat dari beberapa pendapat tokoh seperti B. F. Matthes (Koentjaraningrat, 1995) mengatakan bahwa siri' diterjemahkan dengan malu, rasa kehormatannya, tersinggung, dan sebagainya. Sementara menurut C. H. Salam Basjah (Mattulada, 1995) bahwa terdapat tiga pengertian pada konsep siri'. Pertama ialah dalam arti rasa malu. Kedua, merupakan daya pendorong untuk membinasakan siapa saja yang telah menyinggung rasa kehormatan seseorang, dan ketiga ialah sebagai daya pendorong untuk bekerja dan berusaha sebanyak mungkin. Berbeda dengan pendapat sebelumnya, M. Natzir Said (Koentjaraningrat, 1995) mengemukakan bahwa siri' adalah rasa malu yang memberi kewajiban moril untuk membunuh pihak yang melanggar adat, terutama dalam soal-soal hubungan perkawinan. Budaya siri' juga berfungsi sebagai upaya pengekangan bagi seseorang untuk melakukan tindakan persekusi yang dilarang oleh kaidah adat 
sehingga dapat menguatkan motivasi solidaritas sosial dalam penegakan harkat siri' orang lain (Hijriani \& Herman, 2018).

Adapun sikap positif dari pengaplikasian nilai budaya siri' na pacce adalah individu akan bekerja untuk meningkatkan potensi yang ada pada dirinya. Individu juga akan berusaha mentaati peraturan yang berlaku di masyarakat, menjaga amanah yang telah diterima, dan menjunjung tinggi nilai-nilai kejujuran dalam bekerja. Berdasarkan beberapa hal tersebut, siri' na pacce dapat dijadikan pedoman hidup untuk menumbuhkan sikap positif serta membuat hidup lebih berguna dan bermakna. Sehingga individu bekerja bukan karena hadiah atau imbalan yang akan diterima, tetapi untuk mendapatkan kepuasan diri (Rusdi \& Prasetyaningrum, 2015).

Menurut Hamid et al. (2007), siri' merupakan suatu sistem nilai sosiokultural dan kepribadian yang merupakan pertahanan harga diri dan martabat manusia sebagai individu dan anggota masyarakat. Siri' merupakan kelayakan dalam kehidupan sebagai manusia yang diakui dan diperlakukan oleh sesamanya. Orang yang tidak memperoleh perlakuan yang sama akan merasa harga dirinya dilanggar. Perlakuan yang tidak layak tersebut berupa pelanggaran hak-hak, penghinaan, dan sejenisnya yang dapat menimbulkan reaksi dari orang yang dipakasiri' atau yang dibuat malu. Namun siri' tidak bermakna negatif dan tidak hanya bersifat menentang, tetapi siri' merupakan perasaan halus dan suci. Lebih lanjut Hamid et al. menjelaskan bahwa pacce dalam bahasa Makassar dan pesse dalam bahasa Bugis merupakan rasa kemanusiaan yang adil dan beradab, semangat rela berkorban, bekerja keras, dan pantang mundur. Selain itu pacce atau pesse merupakan suatu perasaan hati yang menyayat pilu terlebih apabila sesama warga masyarakat, keluarga, atau sahabat yang ditimpa kemalangan, yang menimbulkan suatu dorongan ke arah solidaritas dalam berbagai bentuk terhadap mereka yang ditimpa kemalangan. Solidaritas sosial inilah yang mencari sumber moral untuk membentuk tatanan sosial di tengah masyarakat (Hasbullah, 2012).

Rusdi dan Prasetyaningrum (2015) mengemukakan bahwa siri' na pacce merupakan bentuk harga diri, martabat, dan rasa senasib sepenanggungan atau solidaritas dari masyarakat etnis Bugis, Makassar, Mandar, dan Toraja yang dijadikan sebagai pedoman dalam menjalankan kehidupan sehari-hari dan berperilaku baik terhadap individu maupun lingkungannya.

Pendapat senada juga disampaikan oleh Darwis dan Dilo (2012) yang mengemukakan bahwa falsafah siri digunakan oleh orang Makassar untuk membela kehormatan terhadap orang-orang yang mau menghina atau merendahkan harga dirinya, keluarganya, maupun kerabatnya, sedangkan pacce digunakan untuk membantu sesama anggota masyarakat yang berada dalam kesusahan atau mengalami penderitaan. Pacce dapat memupuk rasa persatuan dan kesatuan bangsa, membina solidaritas antara manusia agar mau membantu seseorang yang mengalami kesulitan. Solidaritas inilah yang yang mampu menekankan hubungan antar individu dan kelompok dalam keterikatan bersama yang didukung oleh nilai-nilai moral dan kepercayaan yang hidup dalam masyarakat (Nuraiman, 2019). Dengan kata lain lain solidaritas berarti keadaan di mana individu merasa telah menjadi bagian dari sebuah kelompok.

Dari beberapa pendapat tersebut dapat disimpulkan bahwa siri' na pacce dalam interaksi sosial suku di Makassar merupakan sebagai harga diri dan solidaritas kemanusiaan. Dari konsep siri' sebagai harga diri, dapat dipahami bahwa dalam kehidupan suku di Makassar tidak hanya menuntut penghormatan harga diri individu dari orang lain tetapi bagaimana sesama manusia mampu untuk menghormati dan menjunjung tinggi harkat dan martabat orang lain. Sementara konsep pacce merupakan suatu bentuk solidaritas kemanusiaan dari individu atau kelompok terhadap individu atau kelompok lainnya untuk ikut merasakan kepedihan dan membantu kesulitan yang dialami. Di dalam budaya siri' na pacce mengandung unsur indikator yang dapat meningkatnya solidaritas sosial yaitu nilai kepercayaan, saling hormatmenghormati, bertanggung jawab dan memperhatikan kepentingan bersama. Dengan solidaritas yang muncul diharapkan kecintaan terhadap perbuatan baik akan bertambah.

Dari penjelasan tersebut, maka konsep siri' na pacce bisa dijadikan sebagai jembatan oleh masyarakat di Makassar dan masyarakat lainnya untuk senantiasa saling menghargai, memperkuat solidaritas, mengatasi atau bahkan menghindari konflik-konflik yang terjadi sebagai akibat dari adanya interaksi sosial dalam masyarakat. 


\section{Menghargai Sesama melalui Budaya Sipakatau}

Secara etimologi sikap saling menghargai berarti memberi (menemukan, membumbuhi) harga, menaksir harganya, menghormati, mengindahkan, memandang penting (bermanfaat, berguna). Sikap menghargai orang lain berarti kecenderungan seseorang untuk bereaksi dalam menghormati atau menghargai orang lain. Saling menghargai dalam lisan dan perbuatan merupakan jembatan pemersatu bukan pemisah dalam suatu perbedaan.

Sikap saling menghargai satu sama lain adalah gambaran idaman masyarakat ideal saat ini. Walaupun kadang rasa saling menghargai sering dinodai dengan beda pendapat dan perselisihan. Sikap saling menghargai dapat dijadikan sebagai role model sebuah masyarakat ideal jangka panjang. Hal tersebut tentunya akan menjadi contoh baik bagi generasi muda berikutnya yang pastinya dicecoki dengan berbagai hal positif.

Satu perilaku yang dibutuhkan dalam interaksi interpersonal adalah memberikan penghargaan. Perilaku ini akan sangat penting karena melalui perilaku ini banyak kebutuhan dapat dipenuhi baik pada pihak orang lain maupun pihak diri sendiri meskipun secara tidak langsung. Kebutuhan yang dimaksud adalah kebutuhan untuk dihargai oleh orang lain.

Budaya masyarakat Makassar yang patut dijadikan contoh dalam kehidupan bermasyarakat yang berkaitan dengan nilai saling menghargai adalah budaya sipakatau. Sipakatau berasal dari kata "tau" yang mendapat awalan paka dan imbuhan si. Kata tau dapat diartikan sebagai manusia, ataupun wujud manusia itu sendiri dari jasmani dan rohani. Imbuhan "si" dapat diartikan sebagai sesama sedangkan kata "paka" dapat berarti menghargai sesama. Dengan demikian kata "sipakatau" memiliki makna saling menghormati antara satu sama lain (Patongai dalam Nurnaga, 1999).

Menurut Syarif et al. (2016), sipakatau merupakan sifat untuk memandang manusia seperti manusia. Artinya, dalam menjalani kehidupan sosial kita selayaknya memandang manusia seperti manusia seutuhnya dalam kondisi apapun tanpa melihat dari latar belakang status ekonomi, pendidikan, dan lain sebagainya. Artinya sipakatau merupakan bentuk peng- hormatan terhadap hak asasi manusia dalam masyarakat Makassar. Penghormatan dan perlindungan HAM tersebut mutlak diberikan tanpa pengecualian dan tanpa perbedaan menurut bangsa, suku, ras, agama, jenis kelamin, maupun status sosial dan status hukum dari seseorang (Ndaumanu, 2018). Bahkan secara internasional, pengawalan hak asasi manusia memperoleh legitimasi melalui pengesahan PBB terhadap The Universal Declaration of Human Rights pada tanggal 10 Desember 1945. Oleh karena itu orang Makassar tidak akan memperlakukan manusia lainnya dengan seadanya, tetapi cenderung memandang manusia lainnya dengan penuh martabat hingga siapapun yang berada dalam kondisi tersebut akan senang dan bersemangat (Maida, 2016).

Nilai-nilai sipakatau menunjukkan bahwa budaya orang Makassar memposisikan manusia sebagai makhluk ciptaan Tuhan yang mulia dan oleh karena itu manusia harus dihargai dan diperlakukan secara baik (Rahim, 2019). Semangat inilah yang mendorong tumbuhnya sikap dan tindakan yang tentunya harus diimplementasikan dan diinternalisasikan dalam menjalin pola hubungan sosial dalam bermasyarakat sehingga tercipta suasana yang harmonis yang ditandai dengan adanya hubungan intersubyektifitas dan saling menghargai sebagai sesama manusia. Penghargaan terhadap sesama manusia menjadi landasan utama dalam membangun hubungan yang harmonis antar sesama manusia serta rasa saling menghormati terhadap keberadaban dan jati diri bagi setiap anggota masyarakat.

Sipakatau memiliki makna yang begitu mendalam dalam falsafah suku-suku di Makassar di manapun mereka menetap. Manakala memahami dan kemudian mengamalkannya dalam interaksi kehidupan sehari-hari akan menjadi pribadi yang dirindukan oleh orang lain sehingga falsafah sipakatau dapat membimbing mereka untuk berperilaku sebagai mana layaknya, yaitu pola pikir dan perilaku yang selalu benar, dan tabiat baik (Kaddi \& Dewi, 2017).

Dari beberapa pendapat sebelumnya dapat disimpulkan bahwa budaya sipakatau merupakan budaya suku-suku di Sulawesi Selatan yang menghormati harkat dan martabat manusia sebagai makhluk ciptaan Tuhan yang mulia dan harus diperlakukan selayaknya seperti manusia. Budaya sipakatau juga menjadi penting untuk 
diimplemetasikan oleh manusia dalam menjalani kehidupan sebagai makhluk sosial. Di tengah kemajemukan bangsa Indonesia budaya sipakatau menjadi penting untuk bisa dipahami dan dipatrikan di dalam setiap jiwa sebagai upaya untuk menjaga hubungan dan interaksi sosial tanpa memandang suku, ras, agama, dan budaya agar terjaganya persatuan dan kesatuan bangsa Indonesia.

\section{KESIMPULAN}

$\mathrm{M}$ anusia dalam hakikatnya sebagai makhluk sosial tidak dapat terlepas hubungannya dengan manusia lainnya. Artinya manusia akan selalu saling membutuhkan satu dengan yang lain sehingga tidak dapat terlepas dari proses interaksi sosial. Proses interaksi yang dibangun dapat berupa interaksi positif maupun interaksi negatif. Interaksi positif terjadi apabila terdapat hubungan yang saling menguntungkan sedangkan interaksi negatif terjadi apabila salah satu atau kedua belah pihak dirugikan. Interaksi negatif inilah yang mampu menimbulkan konflik. Konflik-konflik tersebut dapat berupa perselisihan, percekcokan, ketegangan dan lain sebagainya. Bahkan pada tahap yang lebih serius konflik dapat mengancam persatuan dan kesatuan bangsa.

Indonesia adalah bangsa yang majemuk yang memiliki ragam budaya, etnis, bahasa, dan agama. Kemajemukan tersebut selain menjadi khasanah, juga menjadi bumerang bagi persatuan dan kesatuan bangsa Indonesia. Konflik-konflik yang timbul sebagai akibat dari keberagaman budaya, etnis, bahasa, dan agama tersebut dapat diatasi dan dihindari apabila masyarakat Indonesia mampu membangun interaksi sosial yang positif. Konflik tidak dapat dibiarkan begitu saja tanpa ada langkah penyelesaian. Yang terpenting juga adalah langkah prefentif untuk mencegah terjadinya konflik. Dalam menghadapi dan menghindari konflik, diperlukan kebudayaan yang di dalamnya terkandung nilai-nilai normatif karena kebudayaan memiliki kekuatan memaksa pendukungnya untuk mematuhi segala aturan yang melekat. Selain itu, budaya terdiri dari seperangkat nilainilai yang dipelajari, keyakinan, standar-standar, pengetahuan, moral, hukum dan perilaku yang menentukan bagaimana seseorang bertindak. Sulawesi Selatan yang terdiri dari empat suku antara lain suku Bugis, Makassar, Mandar, dan Toraja memiliki ciri khas budaya yang telah menjadi adat istiadat dan falsafah hidup yaitu Siri' Na Pacce dan Sipakatau. Budaya tersebut menjadi pondasi utama dalam menjalani kehidupan mereka sebagai makhluk sosial. Budaya-budaya tersebut mengandung unsur nilai-nilai normatif yang dapat mengikat anggotanya. Melalui siri' mereka mempertahankan harga diri mereka dan malu untuk berbuat tercela sehingga melalui siri' juga mereka belajar untuk menghormati harga diri orang lain. Sementara pacce adalah rasa empati teradap sesama warga, kelurga, dan kerabat yang ditimpa musibah sehingga mendorong rasa solidaritas mereka untuk membantu. Selain kedua budaya tersebut, dalam membangun interaksi sosial yang baik, suku-suku tersebut berpegang pula pada budaya sipakatau yaitu menghormati harkat dan martabat manusia lainnya sebagai makhluk ciptaan Tuhan yang mulia tanpa memandang latar belakang ekonomi, etnis, ras, budaya, maupun strata. Ketiga budaya tersebut harus dapat diimplementasikan dengan baik dan dipertahankan dalam membangun interaksi sosial. Karena melalui interaksi sosial yang baik dalam masyarakat akan terjalin hubungan yang harmonis antar sesama. Dengan demikian kemajemukan Indonesia hanya menjadi khasanah bukan justru menjadi bumerang yang mengancam persatuan dan kesatuan bangsa.

\section{E. UCAPAN TERIMAKASIH}

$\mathrm{P}$ enulis ingin mengucapkan terimakasih kepada Bapak Suharno selaku dosen pembimbing yang telah senantiasa membimbing dan mengarahkan penulis dalam menyusun artikel ini hingga terbit. Terimakasih juga penulis sampaikan kepada Program Pascasarjana Universitas Negeri Yogyakarta yang telah memberi dukungan untuk penerbitan artikel. 


\section{DAFTAR PUSTAKA}

Anggraini, S., Afrizal., \& Indraddin. (2017). Regulasi Konflik Pemilu (Studi Kasus Resolusi Konflik Pilkada 2015 dan Persiapan Pemilu 2019 Di Kabupaten Sijunjung). Jurnal Antropologi: Isu-Isu Sosial Budaya, 21(2), 177-184.

Dharmawan, L. (2019). Konstruksi Konflik dan Elemen-Elemen Budaya pada Kasus Pembakaran Bendera HTI. Jurnal Resolusi Konflik, CSR, dan Pemberdayaan, 4(1), 51-55.

Darwis, R., \& Dilo, A. U. (2012). Implikasi Falsafah Siri' Na Pacce pada Masyarakat Suku Makassar Di Kabupaten Gowa. El Harakah, 14(2), 186-205.

Hamid, A., Farid, Z. A., Mattulada., Lopa, B., \& Salombe, C. (2007). Siri' \& pesse: Harga diri manusia Bugis, Makassar, Mandar, Toraja. Makassar: Pustaka Refleksi

Hasbullah. (2012). Rewang: Kearifan Lokal Dalam Membangun Solidaritas Dan Integrasi Sosial Masyarakat Di Desa Bukit Batu Kabupaten Bengkalis. Jurnal Sosial Budaya, 9(2), 231-243.

Hijriani., \& Herman. (2018). The Value of Siri' na Pacce as an Alternative to Settle Persecution. Padjajaran Journal of Law, 5(3), 558-580.

Irwandi., \& Chotim, E. R. (2017). Analisis Konflik antara Masyarakat, Pemerintah, dan Swasta. Jurnal IImu Sosial dan IImu Politik, 7(2), 24-42.

Kaddi, S. M., \& Dewi, S. R. (2017). Sipakatau, Sipakainge, Sipakalebbi, Sipattokong (Studi Komunikasi Antarbudaya Perantau Bugis di Kota Palu, Sulawesi Tengah). Prosiding Konferensi Nasional Komunikasi, 01(01), 347-357.

Kinasih, K. P., \& Dahliyana, A. (2018). Membangun Solidaritas Peserta Didik Melalui Kegiatan Bakti Sosial Organisasi Siswa Intra Sekolah, Jurnal Sosioreligi, 16(1), 22-28.

Koentjaraningrat, (eds) (1995). 'Manusia dan Kebudayaan di Indonesia', Edisi 15 Jakarta: Djambatan.

Larasati, D. (2018). Globalisasi Budaya dan Identitas: Pengaruh dan Eksistensi Hallyu (KoreanWave) versus Westernisasi di Indonesia. Jurnal Hubungan Internasional,11(1), 109-120.

Magfirah, S. (2016). Siri' Na Pacce dalam Suku Makassar Perspektif Al-Qur'An dan Hadis. TAHDIS, 7(2), 158-170.

Mahmud. (2011). Metode Penelitian Pendidikan. Bandung: Pustaka Setia.

Maida, N. (2016). Seminar Nasional "Pendidikan IImu-IImu Sosial Membentuk Karakter Bangsa dalam Rangka Daya Saing Global", 29 Oktober 2016, Makassar, pp. 327-334.

Mattulada, (1995). Kebudayaan, Kemanusiaan dan Lingkungan Hidup. Makassar: Hasanuddin University Press.

Muslim, A. (2013). Interaksi Sosial dalam Masyarakat Multietnis. Jurnal Diskursus Islam, 1(3), 484494.

Ndaumanu, F. (2018). Kebijakan Pemerintah Daerah Terhadap Upaya Perlindungan Dan Penghormatan Masyarakat Hukum Adat Di Kabupaten Alor Provinsi Nusa Tenggara Timur. Jurnal HAM, 9(1), 37-49.

Nuraiman. (2019). Faktor-Faktor yang Memicu Perubahan Solidaritas Dalam Masyarakat Di Nagari Solok Ambah Kabupaten Sijunjung. Jurnal Ilmu Pendidikan Ahlussunnah 2(2), 6-12.

Ode, S., \& Rachmawati, N. A. (2017). Peran Budaya Lokal Sebagai Media Resolusi Konflik. Jurnal of Goverment, 2(2), 103-119.

Purbasari, V. A., \& Suharno. (2019). Interaksi Sosial Etnis Cina-Jawa Kota Surakarta. Jurnal Antropologi: Isu-Isu Sosial Budaya, 21(2), 1-9.

Rusdi, M. I. W., \& Prasetyaningrum, S. (2015). Nilai Budaya Siri'na Pacce dan Perilaku Korupsi. Jurnal Indigenous, 13(2), 68-86.

Rahim, A. (2019). Internalisasi Nilai Sipakatau, Sipakalebbi, Sipakainge' dalam Upaya Pencegahan Tindak Pidana Korupsi. Jurnal Al-Himayah, 3(1), $29-52$.

Samovar, L. A., Porter, R. E., \& McDaniel, E. R. (2009). Communication Between Cultures. Canada: Lyn Uhl.

Setiadi, E. M., \& Kolip, U. (eds) (2011). 'Pengantar Sosiologi. Pemahaman Fakta dan Gejala Permasalahan Sosial: Teori, Aplikasi, dan Pemecahannya', Edisi 2. Jakarta: Kencana.

Soekanto, S, (eds) (2010). 'Sosiologi Suatu Pengantar', Edisi 43. Jakarta: Rajawali Press.

Soetopo. (1999). Teori Konflik. Jakarta: PT raja Grafindo Persada. 
Sukardi. (2013). Metodologi Penelitian Pendidikan Kompetensi dan Praktiknya. Jakarta: PT Bumi Aksara.

Syarif, E., Sumarmi, Fatchan, A., \& Astina, I. K. (2016). Integrasi Nilai Budaya Etnis Bugis Makassar dalam Proses Pembelajaran sebagai Salah Satu Strategi Menghadapi Era Masyarakat Ekonomi Asean (MEA). Jurnal Teori Dan Praksis Pembelajaran IPS, 1(1), 13-21. 